\title{
Experimental manipulation of leaf litter colonization by aquatic invertebrates in a third order tropical stream
}

\author{
Uieda, VS. ${ }^{a *}$ and Carvalho, EM. ${ }^{b}$ \\ aDepartamento de Zoologia, Instituto de Biociências, Universidade Estadual Paulista “Júlio de Mesquita Filho" - UNESP, \\ CP 510, CEP 18618-970, Botucatu, SP, Brazil \\ bFaculdade de Ciências Biológicas e Ambientais, Universidade Federal da Grande Dourados- UFGD, \\ CP 322, CEP 79804-970, Dourados, MS, Brazil \\ *e-mail: vsuieda@ibb.unesp.br; vsuieda@gmail.com
}

Received: August 13, 2013 - Accepted: January 7, 2014 - Distributed: May 31, 2015

(With 3 figures)

\begin{abstract}
Through a manipulative experiment, the colonization of leaf litter by invertebrates was investigated in two sections of a tropical stream (spatial scale) that differed in function of the canopy cover, one with the presence (closed area) and another without riparian vegetation (open area), during one month of the dry and one of the wet season (temporal scale). The work aimed to verify differences related to four variables: season, canopy cover, leaf type and leaf condition. Litter bags containing arboreal and herbaceous leaves (leaf type variable), non-conditioned and preconditioned (leaf condition variable) were placed at the bottom of the stream in each area (canopy cover variable) and season (dry and wet), and removed after 13-day colonization. The analysis of the remaining litter dry mass per leaf bag emphasizes differences related mainly to seasonality, canopy cover and leaf type, although leaf condition was also important when combined with those three factors. Comparing the abundance of invertebrates per treatment, there was a tendency of high predominance of Chironomidae during the dry season and greater taxa diversity and evenness during the wet season, when the water flow increase could alter the availability of microhabitats for local fauna. Even though canopy cover alone was not a significant source of variation in the abundance of invertebrates, the results showed a tendency of a combined effect of canopy cover with seasonality and leaf condition.
\end{abstract}

Keywords: aquatic insects, leaf breakdown, headwater streams, seasonal variation, spatial variation.

\section{Manipulação experimental da colonização de detritos foliares por invertebrados aquáticos em um riacho tropical de $3^{\mathrm{a}}$ ordem}

\section{Resumo}

Através de um experimento de manipulação, a colonização de detritos foliares por invertebrados foi analisada em duas seções de um riacho tropical (escala espacial), que diferem em função da cobertura do dossel, um com a presença (área fechada) e outro sem vegetação ciliar (área aberta), durante um mês da estação seca e um da chuvosa (escala temporal). O trabalho teve como objetivo verificar as diferenças relacionadas a quatro variáveis: estação, cobertura vegetal, tipo e condição da folha. Sacos de náilon contendo folhas de uma planta arbórea e uma herbácea (tipo folha), não- condicionadas e pré-condicionadas (condição da folha) foram colocadas em cada área e estação do ano e removidos após 13 dias de colonização. A análise da massa seca remanescente dos detritos enfatizou diferenças relacionadas principalmente à sazonalidade, cobertura do dossel e tipo folha, embora a condição da folha também tenha sido importante quando combinado com esses três fatores. Comparando a abundância de invertebrados por tratamento, houve uma tendência de predominância de Chironomidae durante a estação seca e maior diversidade e equidade durante a estação chuvosa, quando o aumento do fluxo de água pode alterar a disponibilidade de micro-habitats para a fauna local. Apesar de cobertura do dossel sozinha não ter sido uma importante fonte de variação na abundância de invertebrados, os resultados mostraram uma tendência de um efeito combinado da cobertura do dossel com a sazonalidade e condição folha.

Palavras-chave: insetos aquáticos, decomposição foliar, riachos de cabeceira, variação temporal, variação espacial.

\section{Introduction}

Due to the important role of riparian zone in the stream integrity and as a energy source to the stream and the aquatic fauna (see Rodrigues and Leitão-Filho, 2001; Callisto et al., 2012), studies that demonstrate the relationship between the quality of allochthonous material

and invertebrates colonization are greatly important to predict possible impacts on the aquatic ecosystem.

Although it has lower physical stability than rock substrate, leaf litter of allochthonous origin also has an important role in the structuring of stream invertebrate 
community (Uieda and Motta, 2007), enabling litter colonization by a high density and diversity of organisms (Gonçalves Junior et al., 2006a, b; Crisci-Bispo et al., 2007; Junke and Trivinho-Strixino, 2007; Moretti et al., 2007; Abelho, 2008; Carvalho et al., 2008; Schindler and Gessner, 2009). This material of allochthonous origin is fundamental for energy flow and carbon stocks of low-order streams with riparian vegetation (Vannotte et al., 1980; Wallace et al., 1997), and its decomposition constitutes a key process in the structure and metabolism of river systems (Cummins, 1988).

The removal of riparian vegetation was clearly reflected in the low contribution of leaf litter to the stream (Carvalho and Uieda, 2010) and in the increase of light incidence (Rodrigues and Leitão-Filho, 2001). Those modifications can have a potential effect on the invertebrate community structure, with a reduction of the shredder's functional group and an increase of primary consumers (Carvalho and Uieda, 2009a). The invertebrate leaf specialists are considered micro-endemic, and are particularly vulnerable to deforestation (Cummins and Klug, 1979; Benstead and Pringle, 2004; Baxter et al., 2005).

The riparian vegetation has influence on the composition and organization of macroinvertebrate community. Previous studies have shown that leaf litter of different plant species is colonized by different invertebrates (Junke and Trivinho-Strixino, 2007; Abelho, 2008) and also presented data reinforcing that shredder invertebrates are able to discriminate among leaf types (Abelho, 2001; Graça, 2001). Thus, the structure of riparian vegetation will determine the nature of the allochthonous matter entering the aquatic environment, which in turn could have an influence on the structure of the aquatic invertebrate assemblages.

The quality of the litter can be related not only with its nutritional value but also with its palatability (Cummins, 1974). Microorganisms that contribute to leaf breakdown can also improve the leaf attractiveness and nutritional value for invertebrates (Cummins, 1974). As reported by Graça and Canhoto (2006), tropical shredders feed selectively on microbial colonized leaves ("conditioned leaves"), with a reduction on the invertebrates growth rate in the absence of microbial assemblages in leaves. Thus, it will be interesting to elucidate if microbial conditioning of leaves also has effects on the abundance and richness of invertebrate assemblages.

The amount of leaf litter input, influenced by seasonal climatic/hydrologic variations, can have also a potential effect on the invertebrate community structure. In temperate deciduous forests, a marked seasonal variation in input rate, higher in autumn, was found (Abelho and Graça, 1998). But in tropical forests, the litterfall rate can be non-synchronous when leaf litter keeps entering at a relatively constant rate throughout the year (Abelho, 2001; Gonçalves Junior et al., 2006a, b), or it can be seasonal, when a marked dry season occurs. A higher input can occur in the late dry season in semi-deciduous forests (Uieda and Kikuchi, 1995; Afonso et al., 2000; Gonçalves Junior and Callisto, 2013) or in the peak of the wet season in the
Atlantic rain forest (Rezende and Mazzoni, 2005). These temporal variations of leaf litter input may be related to the phenology of the riparian vegetation and to the discharge regime (Pozo et al., 1997; Gonçalves Junior and Callisto, 2013).

Through a manipulative experiment, the colonization of leaf litter by invertebrates was investigated in a tropical stream. Previous studies done in the same area confirmed a spatial and seasonal variation of litter input (Carvalho and Uieda, 2010), litter mass loss (Carvalho and Uieda, 2009b) and invertebrate diet (Carvalho and Uieda, 2009a). It needs to be reinforced that, although for a better spatial and seasonal analysis it will be recommended to evaluate more than one stream and year, this work is part of a broad study of the dynamic of the leaf litter input and process, what logistically could be done only in a small spatial and temporal scale. Then, the spatial (restricted to two sites in a stream) and seasonal (two seasons in one year) results needs to be viewed with caution and inside the broad context of the work. For the litter colonization by invertebrates here studied, the hypothesis is that there will also be a spatial and seasonal difference, concomitantly verifying the influence of the riparian vegetation integrity, seasonality, and type of leaf litter on the colonization process. An increase of invertebrate abundance is expected: a) in sites with riparian vegetation integrity and, consequently, higher leaf litter input, b) during the periods of the highest values of leaf litter input and lowest values of discharge and, consequently, more leaf litter stability as in a drought season, c) in leaves with less defense characteristics and low concentration of fiber and cellulose, d) in leaves colonized by microbes (bacteria and fungi) that make them more attractive for invertebrates.

\section{Material and Methods}

\subsection{Study area}

The present study was carried out in a southeastern Brazilian stream, named Ribeirão da Quinta, located in the municipality of Itatinga, state of São Paulo (2306'47"'S, 48²9'46"W), from June 19 to July 15 (dry season) and from November 16 to December 12, 2004 (wet season). The studied stream stretch is a 3rd order stream (according to Strahler classification in Stanford, 1996) and rises in the escarpments at the eastern edge of the Botucatu mountain range (Cuesta de Botucatu), at an altitude of 750 meters, comprising part of the Alto Paranapanema River Basin.

Two areas, covering an extension of approximately $120 \mathrm{~m}$ each and located at a distance of 200 meters apart, were selected for this study. The downstream area, named "open area", presents herbaceous vegetation on its banks, which allows solar radiation to fall directly upon the stream. The herbaceous plants Pycreus decumbens T. Koyama (Cyperaceae), Hedychium coronarium J. Konig (Zingiberaceae) and Panicum L. (Gramineae) are predominant in this area. The upstream area, called "closed area", presents riparian vegetation represented mainly by the tree species Nectandra 
Rol. Ex Rottb. (Lauraceae), Cabralea canjerana (Vell.) Mart. (Meliaceae), Acacia Mill., Inga Mill., Piptadenia gonoacantha (Mart.) J.F. Macbr. (Mimosaceae), Mollinedia Ruiz \& Pavón (Monimiaceae), Coutarea hexandra (Jacq.) K. Schum. (Rubiaceae), Esenbeckia febrifuga (A. St.-Hil.) A. Juss. Ex Mart. (Rutaceae), the climbing plant Smilax L. (Liliaceae), and the herbaceous plant Urera baccifera (L.) Gaudich. Ex Wedd. (Urticaceae).

The physical and chemical parameters measured during the dry and wet seasons (Table 1) emphasize seasonal differences like lower values of temperature and discharge, and higher values of conductivity during the dry season, and spatial differences like values of current velocity twice higher in the open area.

\subsection{Experiment setup}

Leaves from the two most abundant plant species were used in the experiment, an invasive herbaceous plant ( $P$. decumbens) represents the open area and a native arboreal plant (C. canjerana) represents the closed area. The concentration of acid detergent fibers (ADF), lignin and cellulose of both plant species were previously determined, with higher percentages of ADF and cellulose for the arboreal leaves (Carvalho and Uieda, 2009b). Green fresh leaves of both plants were collected directly from the trees, air dried and placed separately in coarse-mesh bags, $5 \pm 0.05 \mathrm{~g}$ of leaf matter per bag. The litter bags were made of rigid plastic mesh $(20 \times 15 \mathrm{~cm}, 10 \mathrm{~mm}$ mesh $)$, allowing access to leaves not only for small invertebrates but also for the largest ones present in the stream. The green leaves were chose because they were found in greater quantity than senescent leaves in the litter.

Before starting the experiment, the litter bags were prepared to analyze the influence of prior microbial conditioning of leaves on the abundance and richness of invertebrate assemblages. For each season, 20 arboreal litter bags and 20 herbaceous litter bags were also wrapped in fine-mesh bags $(250 \mu \mathrm{m}$ mesh, enough to prevent the entry of most macroinvertebrates) and submerged in the stream for a 14 day microbial colonization. This time period was determined by Abelho (2001) as enough for a significant proportion of colonization by microorganisms to be completed. After this conditioning period, the external fine-mesh of those bags was removed (representing the preconditioned treatment) and other 40 new litter bags ( 20 of each plant wrapped only in the coarse-mesh), representing the non-conditioned treatment made by fresh leaves were also placed in the stream bottom. This was considered day 1 of invertebrate colonization for non-conditioned and preconditioned litter (from now on called fresh leaves and conditioned leaves, respectively).

Sixteen treatments were tested using a combination of four factors: a) seasonality - dry and wet season, b) canopy cover - open and closed area, c) leaf type - herbaceous and arboreal, d) leaf condition - fresh and conditioned. The experimental design had a total of 160 litter bags distributed into sixteen treatments, and 10 samples of litter bags per treatment.

After 13 day invertebrate colonization, all litter bags ( 80 on each season) were removed. This maximum period of colonization was chosen to ensure reliable determination of the remaining litter mass. Previous studies have shown that the two studied plants reached about $50 \%$ of mass loss between 13-17 day incubation (Carvalho and Uieda, 2009b). The litter bags were carefully hung, packaged into plastic bags and stored in a cool box containing ice for transportation. In the laboratory, the leaves were carefully washed and the resulting matter was inspected under a stereomicroscope for macroinvertebrates sorting. The separated animals were stored in flasks with $70 \%$ ethanol, and subsequently counted and identified by the genus level, whenever possible. The method used to determine the initial and final leaf dry mass is described in Carvalho and Uieda (2009b).

\subsection{Data analysis}

Data of abundance and richness of invertebrates per treatment were used to calculate the Shannon-Wiener diversity and Simpson's evenness (Krebs, 1989). To analyze the similarity between treatments a hierarchical cluster analysis (group average) and a non-metric multi-dimensional scaling analysis (NMDS) were applied to the abundance data $(\log (x+1))$, using a Bray Curtis measured of similarity to create the resemblance matrix (Primer v.6; Clarke and Gorley, 2006).

The remaining litter mass and the macroinvertebrate abundance were previously tested for normality (Shapiro-Wilk; $\alpha=0.05$ ) and homocedasticity (Levene; $\alpha=0.05$; STATSOF, 1996). The square root transformation was applied to remaining litter mass data (Zar, 1999). The differences between treatments for the remaining litter mass per litter bag and for the total invertebrate abundance were analyzed by a factorial Analysis of Variance (Statsoft, 1996). Significance was determined under the assumption

Table 1. Abiotic parameters determined during the experimental study carried out in two areas of Ribeirão da Quinta during the dry (June-July 2004) and wet (November-December 2004) seasons (mean of 4 measurements \pm standard deviation).

\begin{tabular}{ccccc}
\hline & \multicolumn{2}{c}{ Dry season } & \multicolumn{2}{c}{ Wet season } \\
\hline Parameters & Open area & Closed area & Open area & Closed area \\
\hline Temperature $\left({ }^{\circ} \mathrm{C}\right)$ & $17.5 \pm 1.2$ & $16.9 \pm 1.5$ & $22.0 \pm 0.3$ & $21.7 \pm 0.3$ \\
$\mathrm{pH}$ & $8.0 \pm 0.1$ & $7.9 \pm 0.2$ & $8.0 \pm 0.1$ & $7.9 \pm 0.1$ \\
Conductivity $\left(\mu \mathrm{S} . \mathrm{cm}^{-1}\right)$ & $96.0 \pm 11.0$ & $96.0 \pm 11.0$ & $80.0 \pm 10.0$ & $80.0 \pm 10.0$ \\
Current velocity $\left({\left.\mathrm{m} . \mathrm{s}^{-1}\right)}^{0}\right.$ & $0.3 \pm 0.0$ & $0.1 \pm 0.0$ & $0.3 \pm 0.0$ & $0.1 \pm 0.0$ \\
Discharge $\left(\mathrm{m} 3 . \mathrm{s}^{-1}\right)$ & $0.2 \pm 0.0$ & $0.2 \pm 0.0$ & $0.2 \pm 0.0$ & $0.2 \pm 0.0$ \\
\hline
\end{tabular}


that treatment combination was a random factor. For the most abundant groups (a total of 14 taxa with a relative abundance $>1 \%$ in at least one season), the seasonal difference in abundance was analyzed by a nested Analysis of Variance (Statsoft, 1996).

\section{Results}

The analysis of the remaining litter dry mass per leaf bag emphasizes differences related mainly to seasonality, canopy cover and leaf type, although leaf condition was also important when combined with those three factors (Table 2). Data from the dry season presented more similarities among treatments (Figure 1). On the other hand, data from the wet season showed a faster decomposition process in the closed area and conditioned leaf treatments (Figure 1).

Analyzing data of the total invertebrates' abundance per treatment (dataset showed in Uieda and Carvalho, 2013), a seasonal pattern was also emphasized (Table 3), with more differences related to seasonality, alone and combined with other three factors. Also, the abundance data from the dry season treatments were more similar than the wet ones (Figure 2). Although canopy cover alone was not a significant source of variation of invertebrate abundance data (Table 3), when combined with seasonality and leaf condition this factor may be responsible for the lowest abundance values during the wet season, at the closed area and for conditioned leaves (Figure 2).

The results of the cluster and NMDS analysis (Figure 3) clearly stressed the importance of seasonality and canopy cover when compared the abundance of invertebrates per treatment, without a clear pattern for leaf type and condition. The samples of each area were grouped per season with a $70 \%$ of similarity (Figure 3 ).

Thirty-two taxonomic groups were sampled, represented mainly by insects, predominantly Diptera

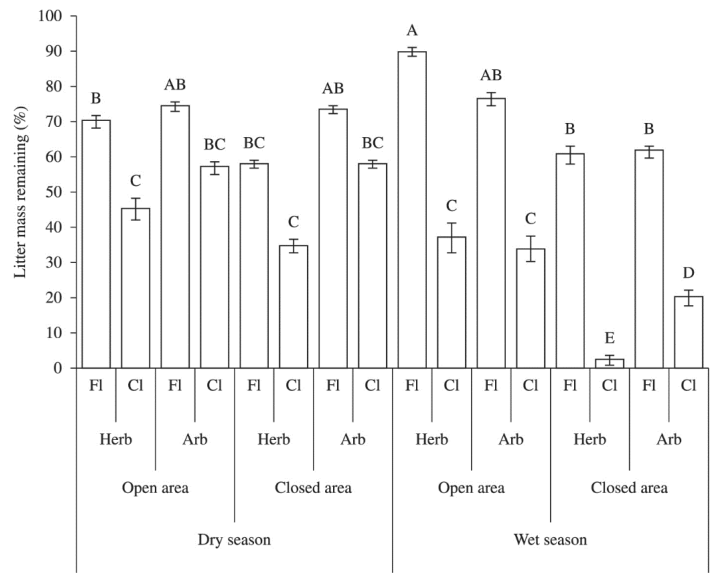

Figure 1. Litter dry mass remaining (mean \pm SE) per treatment: season (dry and wet), canopy cover (open and closed areas), leaf type (Herb- herbaceous and Arb- arboreal) and leaf condition (Fl- fresh and $\mathrm{Cl}$ - conditioned). Letters above the bars are the results of Tukey's HSD test, and similar letters indicate homogeneous groups.
(47\%), Ephemeroptera (31\%) and Trichoptera (18\%), and mainly by the collector feeding group (Table 4$)$. The genus Phylloicus (Trichoptera) was the only shredding specialist insect, sampled mainly during the wet season (Table 4) and in the closed area (data showed by Carvalho and Uieda, 2009a).

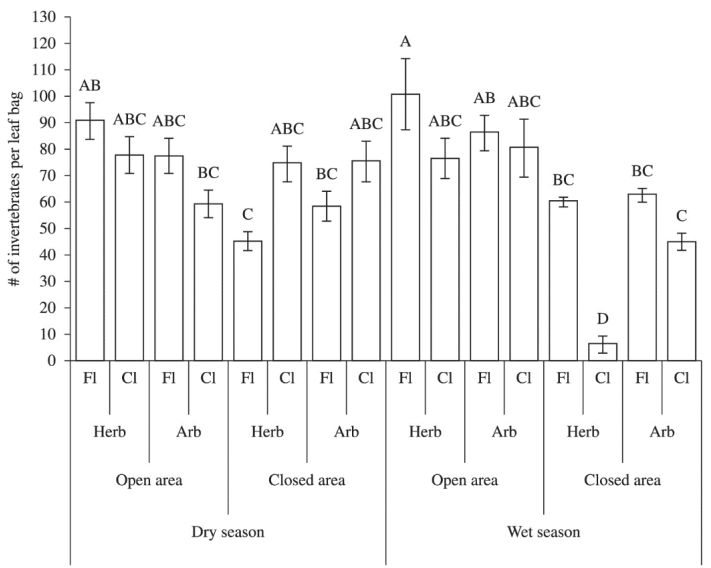

Figure 2. Total invertebrates (mean $\pm \mathrm{SE}$ ) per treatment: season (dry and wet), canopy cover (open and closed areas), leaf type (Herb- herbaceous and Arb- arboreal) and leaf condition (Fl- fresh and Cl- conditioned). Letters above the bars are the results of Tukey HSD test, and similar letters indicate homogeneous groups.
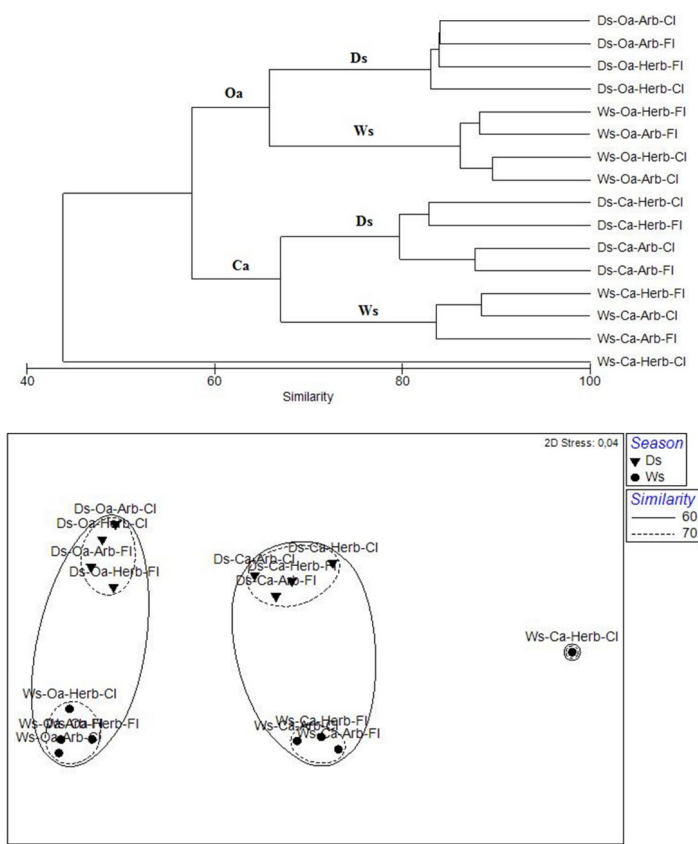

Figure 3. Results of the hierarchical cluster analysis (group average) and the non-metric multi-dimensional scaling analysis (NMDS) applied to the invertebrates' abundance data $(\log (\mathrm{x}+1))$, considering the following treatments: season (Ds- dry and Ws- wet), canopy cover (Oa- open area and $\mathrm{Ca}$ - closed area), leaf type (Arb- arboreal and Herb- herbaceous) and leaf condition (Fl- fresh and Cl- conditioned). 
Table 2. Results of factorial Analysis of Variance (ANOVA) to test effects of seasonality, canopy cover, leaf type and leaf condition (total of 16 combinations) on remaining leaf mass after 13-day decomposition in a stream. SS (\%) refers to percentage of the total square sum.

\begin{tabular}{lrrrc}
\hline \multicolumn{1}{c}{ Variation source } & SS (\%) & df & F & p \\
\hline Seasonality (dry and wet season) & 9.06 & 1 & 153.0 & $<0.001^{*}$ \\
Canopy cover (open and closed area) & 10.11 & 1 & 170.6 & $<0.001^{*}$ \\
Leaf type (herbaceous and arboreal) & 3.74 & 1 & 63.2 & $<0.001^{*}$ \\
Leaf condition (fresh and preconditioned) & 44.32 & 1 & 748.3 & 0.636 \\
Seasonality $\times$ Canopy cover & 5.13 & 1 & 86.6 & $0.002^{*}$ \\
Seasonality $\times$ Leaf type & 0.12 & 1 & 2.0 & 0.163 \\
Seasonality $\times$ Leaf condition & 11.54 & 1 & 194.9 & $<0.001^{*}$ \\
Canopy cover $\times$ Leaf type & 3.53 & 1 & 59.6 & $<0.001^{*}$ \\
Canopy cover $\times$ Leaf condition & 1.33 & 1 & 22.5 & $<0.001^{*}$ \\
Leaf type $\times$ Leaf condition & 2.57 & 1 & 43.5 & $<0.001^{*}$ \\
Error & 8.53 & 144 & & \\
\hline
\end{tabular}

*Significance level at $\mathrm{p}<0.01$.

Table 3. Results of factorial Analysis of Variance (ANOVA) to test effects of seasonality, canopy cover, leaf type and leaf condition (total of 16 combinations) on total invertebrates abundance per leaf bag. SS (\%) refers to percentage of the total square sum.

\begin{tabular}{lrrrr}
\hline \multicolumn{1}{c}{ Variation source } & SS (\%) & df & F & p \\
\hline Seasonality (dry and wet season) & 1.31 & 1 & 1522.9 & $<0.001^{*}$ \\
Canopy cover (open and closed area) & 38.41 & 1 & 2.2 & 0.139 \\
Leaf type (herbaceous and arboreal) & 0.13 & 1 & 65.0 & $<0.001^{*}$ \\
Leaf condition (fresh and preconditioned) & 5.85 & 1 & 0.2 & 0.636 \\
Seasonality $\times$ Canopy cover & 10.76 & 1 & 9.9 & $0.002^{*}$ \\
Seasonality $\times$ Leaf type & 1.81 & 1 & 18.2 & $<0.001^{*}$ \\
Seasonality $\times$ Leaf condition & 10.66 & 1 & 12.8 & $<0.001^{*}$ \\
Canopy cover $\times$ Leaf type & 7.54 & 1 & 3.1 & 0.082 \\
Canopy cover $\times$ Leaf condition & 0.98 & 1 & 18.0 & $<0.001^{*}$ \\
Leaf type $\times$ Leaf condition & 1.08 & 1 & 1.7 & 0.201 \\
Error & 21.48 & 144 & & \\
\hline
\end{tabular}

*Significance level at $\mathrm{p}<0.01$.

Table 4. Total abundance of invertebrates in all leaf bags incubated in Ribeirão da Quinta, during the dry (Ds) and wet season (Ws), functional feeding groups $(\mathrm{Pr}=$ Predator, $\mathrm{Co}=$ Collector, $\mathrm{Sh}=$ Shredder, $\mathrm{Sc}=$ Scraper, $?=$ unknown $)$ and results of ANOVA used for seasonal comparison of the most abundant groups.

\begin{tabular}{|c|c|c|c|c|c|}
\hline Taxonomic groups & Ds & Ws & FFG & $\mathbf{F}$ & $\mathbf{p}$ \\
\hline \multicolumn{6}{|l|}{ MOLLUSCA - GASTROPODA } \\
\hline Ancylidae & 119 & 728 & $\mathrm{Sc}$ & 31.41 & $<0.001$ \\
\hline Lymnaeidae & - & 72 & $\mathrm{Sc}$ & - & - \\
\hline \multicolumn{6}{|l|}{ ARTHROPODA - CRUSTACEA } \\
\hline Aeglidae - Aegla castro Schmidt, 1942 & - & 12 & $?$ & - & - \\
\hline \multicolumn{6}{|l|}{ ARTHROPODA - INSECTA } \\
\hline \multicolumn{6}{|l|}{ Coleoptera } \\
\hline Elmidae - Heterelmis Sharp, 1882 & 227 & 419 & $\mathrm{Co}$ & 8.10 & $<0.001$ \\
\hline Gyrinidae & 2 & 13 & $\operatorname{Pr}$ & - & - \\
\hline \multicolumn{6}{|l|}{ Diptera } \\
\hline Chironomidae & 5107 & 1906 & $\mathrm{Pr} / \mathrm{Co}$ & 53.80 & $<0.001$ \\
\hline Empididae & 16 & 106 & Co & 28.81 & $<0.001$ \\
\hline Simuliidae - Simulium lutzianum Pinto, 1932 & 655 & 11 & $\mathrm{Co}$ & 17.13 & $<0.001$ \\
\hline \multicolumn{6}{|l|}{ Ephemeroptera } \\
\hline Baetidae - Americabaetis Kluge, 1992 & 739 & 491 & $\mathrm{Co}$ & 3.33 & 0.07 \\
\hline
\end{tabular}


Table 2. Continued...

\begin{tabular}{|c|c|c|c|c|c|}
\hline $\begin{array}{r}\text { Taxonomic groups } \\
\end{array}$ & Ds & Ws & FFG & $\mathbf{F}$ & $\mathbf{p}$ \\
\hline Baetidae - Baetodes Needham \& Murphy, 1924 & 264 & 1 & $\mathrm{Sc}$ & 19.57 & $<0.001$ \\
\hline Baetidae - Cloeodes Traver, 1938 & 5 & - & Co & - & - \\
\hline Baetidae - Camelobaetidius Demouling, 1966 & - & 1 & $\mathrm{Co}$ & - & - \\
\hline Caenidae - Caenis Stephens, 1835 & - & 7 & Co & - & - \\
\hline Leptohyphidae - Traverhyphes Molineri, 2001 & 1231 & 941 & Co & 9.64 & $<0.001$ \\
\hline Leptohyphidae - Tricorythopsis Traver, 1958 & - & 20 & Co & - & - \\
\hline Leptophlebiidae - Farrodes Peter, 1971 & 472 & 289 & Co & 38.68 & $<0.001$ \\
\hline $\begin{array}{l}\text { Leptophlebiidae - Meridialaris Peter \& Edmunds, } \\
1972\end{array}$ & 3 & - & $?$ & - & - \\
\hline $\begin{array}{l}\text { Heteroptera - Pleidae - Neoplea Esaki \& China, } \\
1928\end{array}$ & 18 & 4 & $\operatorname{Pr}$ & - & - \\
\hline Lepidoptera - Pyralidae - Nymphulinae & - & 1 & $\mathrm{Sh} / \mathrm{Sc}$ & - & - \\
\hline $\begin{array}{l}\text { Megaloptera - Corydalidae - Corydalinae } \\
\text { Odonata }\end{array}$ & 1 & - & $\operatorname{Pr}$ & - & - \\
\hline Calopterygidae - Hetaerina Selys, 1853 & 22 & 13 & $\operatorname{Pr}$ & - & - \\
\hline $\begin{array}{l}\text { Megapodagrionidae - Heteragrion Salys, } 1862 \\
\text { Plecoptera }\end{array}$ & - & 11 & $\operatorname{Pr}$ & - & - \\
\hline Gripopterygidae - Paragripopteryx Enderlein, 1909 & 2 & - & $?$ & - & - \\
\hline Gripopterygidae - Tupiperla Froehlich, 1969 & 13 & - & $\mathrm{Sc}$ & - & - \\
\hline $\begin{array}{l}\text { Perlidae - Anacroneuria Klapálek, } 1909 \\
\text { Trichoptera }\end{array}$ & 45 & 60 & $\operatorname{Pr}$ & - & - \\
\hline Calamoceratidae - Phylloicus Müller, 1880 & 12 & 169 & $\mathrm{Sh}$ & 19.09 & $<0.001$ \\
\hline Glossosomatidae - Protoptila Banks, 1904 & 6 & 29 & $\mathrm{Sc}$ & - & - \\
\hline Hydropsychidae - Smicridea McLachlan, 1871 & 124 & 615 & Co & 17.94 & $<0.001$ \\
\hline Hydroptilidae - Neotrichia Morton, 1905 & 264 & 175 & $\mathrm{Sc}$ & 4.44 & $<0.001$ \\
\hline Hydroptilidae - Ochrotrichia Mosely, 1934 & 17 & 222 & Co & 20.74 & $<0.001$ \\
\hline Hydroptilidae - Hydroptila Dalman, 1819 & 40 & 692 & $\mathrm{Sc}$ & 34.71 & $<0.001$ \\
\hline Leptoceridae - Nectopsyche Müller, 1879 & 2 & 8 & $\operatorname{Pr}$ & - & - \\
\hline Abundance & 9406 & 7016 & & & \\
\hline Richness & 25 & 27 & & & \\
\hline Diversity & 5.177 & 6.132 & & & \\
\hline Evenness & 0.140 & 0.318 & & & \\
\hline
\end{tabular}

As the variance, cluster and NMDS analysis emphasized seasonality being a significant source of total invertebrate abundance variation, this factor was also tested for the 14 most abundant taxonomic groups. The results showed the seasonal influence also on the invertebrate community composition, seven groups with significantly higher abundance in the wet season and six in the dry season (Table 4).

Taxon richness, diversity and evenness showed a tendency of higher values in the wet season, although 20 groups ( $62 \%$ of the total) were common to both seasons (Table 4). On the other hand, the abundance was higher in the dry season, when a significant predominance of Diptera-Chironomidae was also found ( $54 \%$ of the total).

\section{Discussion}

The results of the colonization experiment allowed the confirmation of some of the initial hypotheses. The invertebrate composition presented a marked pattern of seasonality regarding the predominance of specific groups on each season. Although the influence of the spatial factor was not so strong than the seasonal, when combined with leaf type and condition this factor determined a reduction of the abundance of invertebrates at the closed area, during the wet season and on conditioned leaves, which reinforces the importance of research that integrates different factors in studies of the structure and organization of invertebrate community.

The invertebrate assemblages sampled in this study were similar to those found in other colonization experiments carried out in the same stream, regarding the fauna associated with leaf litter (Carvalho et al., 2008), or even with rocky substrate (Carvalho and Uieda, 2004, 2006; Ribeiro and Uieda, 2005; Carvalho et al., 2008). Data found in the literature highlight not only the importance of rocks, but also of leaf litter deposited on them as a substrate for the macroinvertebrate fauna consisting mainly of aquatic insects, with a predominance of Diptera-Chironomidae, followed by Ephemeroptera, Trichoptera and Coleoptera orders. 
Moreover, the low diversity of shredding specialists when compared to the wide diversity of invertebrates associated with leaf litter suggests that this matter is used more as a substrate than directly as a food source.

In the present study, a distinct pattern of seasonality was found and the composition of most representative groups varied in each season. The dry season was characterized by a high predominance of Chironomidae, maybe related to an increase of organic matter deposition in the stream channel in function of the lower values of rainfall and discharge during this season (see Carvalho and Uieda, 2010). On the other hand, the higher values of diversity and evenness found for wet season data may be related to a less dominance of Chironomidae. The increase in rainfall and discharge during the wet season (see Carvalho and Uieda, 2010) could create a physical homogenization of substrates which allowed the occurrence of more rare species in the presence of less dominant groups. However, the higher physical stability during the dry season can be associated with a strong effect of biotic interactions, enabling the dominance of some species (Allan, 1995).

A number of studies analyzing the composition of invertebrates in Brazilian streams have also demonstrated the existence of a seasonal pattern in the structure of this community, with a tendency towards a greater number of individuals during the longer drought periods (Uieda and Gajardo, 1996; Oliveira and Froehlich, 1997; Bispo and Oliveira, 1998; Kikuchi and Uieda, 1998; Callisto et al., 2004; Ribeiro and Uieda, 2005; Bispo et al., 2006). Seasonal patterns could be a result of a series of interdependent factors, such as intrinsic characteristics of the environment and regional climatic factors that could act together. Those factors can define seasonal variations in the species cluster that sometimes benefits from seasonal effects, and sometimes from biotic interactions favored by a more stable environment, as found by some authors (Allan, 1995; Carvalho et al., 2008; Leung and Dudgeon, 2011). Flood events during the wet season could alter the availability of microhabitats, like leaf litter, which normally act as a shelter for local fauna (Bispo et al., 2006).

A large part of the variation in the abundance of aquatic fauna is determined not only by regional climatic aspects, but also by their interaction with small spatial scale stream characteristics, such as substrate stability, current velocity and riparian vegetation (Callisto et al., 2004; Bispo et al., 2006). Differences in the immediate surroundings of both sampled areas in this study may be an important factor on the structure of the invertebrate community, although there was no clear variation in the abundance of these organisms when studied the spatial factor alone. Although the pasture surrounding the open area may reduce the lateral input of organic matter to the stream, the local community could benefit from the large input of drifting allochthonous matter transported from the upstream stretch bordered by gallery forest (Carvalho and Uieda, 2010). As for the dipteran Simuliidae, the ephemeropterans Americabaetis and Baetodes and the trichopterans Smicridea and Hydroptila, Carvalho and
Uieda (2009a) found a diet based mainly on fine particulate organic matter (FPOM), confirming the importance of the allochthonous material input as a food source for many aquatic macroinvertebrates.

Analyzing Brazilian streams that are subject to different degrees of riparian vegetation loss, Silva-Junior and Moulton (2011) did not found any spatial influence upon the diversity of invertebrate taxa but inferred an effect of habitat degradation on the microbial decomposition of leaf litter as they found a significant faster rate of leaf processing in the streams with preserved riparian vegetation. In Ribeirão da Quinta we found an influence of habitat degradation not only in the rate of decomposition, faster in the stretch with riparian vegetation (Carvalho and Uieda, 2009b), but also in the diversity of taxa. In the present study, the typical leaf-shredding trichopteran Phylloicus occurred mainly in the area with gallery forest (Carvalho and Uieda, 2009a), which could be related to its dependence on leaves, both for feeding and construction of its case. The greater abundance of Phylloicus in the wet season samples could be related to its life cycle and to the greater input of leaves in this season, as found by Carvalho and Uieda (2010). These specialists in allochthonous material are often micro-endemic, depend on food sources of allochthonous origin, and are particularly vulnerable to alterations in riparian vegetation (Benstead and Pringle, 2004).

The results of the number of individuals which colonize leaves from arboreal and herbaceous plants emphasize a significant tendency of fewer invertebrates colonizing herbaceous conditioned leaves, associated with canopy cover (closed area). Those results may be related with differences in the decomposition process of both types of leaves. As analyzed by Carvalho and Uieda (2009b), the decomposition of leaves from the invasive herbaceous plant (P. decumbens) was significantly faster than leaves from the native arboreal plant (C. canjerana), mainly during the wet season and in the closed area. This faster decomposition rate may be related to the chemical properties of the plants, as a lower concentration of fibers and cellulose in the herbaceous leaf when compared to the arboreal one (Carvalho and Uieda, 2009b). Those characteristics may be responsible for a low resistance of $P$. decumbens to the lixiviation process and probably to the action of microorganisms. Consequently, this great loss of leaf area for colonization by the invertebrate community may be the cause of the reduction on their abundance found in the herbaceous leaf.

In conclusion, seasonality was the factor that has explained better our hypotheses, although it needs to be viewed with caution because of the absence of temporal replicates. This factor showed significant differences both in the leaves decomposition process and colonization by invertebrates, with a definition of groups of species that benefit from the extreme seasonal effects of the wet season, whereas others were favored by the physical stability of the dry season. Even though canopy cover alone was not a significant source of variation in the abundance of invertebrates, and also this spatial scale was not replicated, 
the results showed a tendency of a combined effect of canopy cover with seasonality and leaf condition.

A possible selection of invertebrates by herbaceous conditioned leaves was apparent in the closed area and during the wet season. Some studies have also shown patterns of preference or attractiveness based on the type or quality of leaves, but generally they were carried out in laboratory, where environmental variables can be controlled. Experiments in situ generally need to deal with a great variety of factors, which can shade the effect of each factor separately. As it was observed in the present study, the complexity of factors in tropical streams may require an even greater challenge to the understanding of colonization patterns of invertebrates, with an increase of the spatial and seasonal scales and of the analyzed abiotic factors.

\section{Acknowledgements}

We thank Fabio Vitta (Botanical Institute of São Paulo) and Clemente J. Campos (Unesp - Univ Estadual Paulista, Botucatu) for identifying the plants; Michéle O.D.A. Corrêa and Hamilton A. Rodrigues for their assistance in the fieldwork; Claudio G. Froehlich, Marcos Callisto and Rosinês Luciana da Motta for critical comments on an earlier version of the manuscript. The second-named author was founded by a scholarship from the National Council for Scientific and Technological Development (CNPq).

\section{References}

ABELHO, M., 2001. From litterfall to breakdown in streams: a review.The Scientific World Journal, vol. 1, p. 656-680. http:// dx.doi.org/10.1100/tsw.2001.103. PMid:12805769

ABELHO, M., 2008. Effects of leaf species on macroinvertebrate colonization during decomposition in a Portuguese stream. International Review of Hydrobiology, vol. 93, no. 3, p. 358-371. http://dx.doi.org/10.1002/iroh.200711019.

ABELHO, M. and GRAÇA, MAS., 1998. Litter in a first-order stream of a temperate deciduous forest (Margaraça Forest, central Portugal).Hydrobiologia, vol. 386, no. 1-3, p. 147-152. http:// dx.doi.org/10.1023/A:1003532921432.

AFONSO, AAO., HENRY, H. and RODELLA, RCSM., 2000. Allochthonous matter input in two different stretches of a headstream (Itatinga, São Paulo, Brazil).Brazilian Archives of Biology and Technology, vol. 43, no. 3, p. 335-343. http://dx.doi.org/10.1590/ S1516-89132000000300014.

ALLAN, JD., 1995. Stream ecology: structure and function of running waters. London: Chapman \& Hall. 388 p.

BAXTER, CV., FAUSCH, KD. and SAUNDERS, WC., 2005. Tangled webs: reciprocal flows of invertebrate prey link stream and riparian zones.Freshwater Biology, vol. 50, no. 2, p. 201-220. http://dx.doi.org/10.1111/j.1365-2427.2004.01328.x.

BENSTEAD, JP. and PRINGLE, CM., 2004. Deforestation alters the resource base and biomass of endemic stream insects in eastern Madagascar.Freshwater Biology, vol. 49, no. 4, p. 490-501. http:// dx.doi.org/10.1111/j.1365-2427.2004.01203.x.
BISPO, PC. and OLIVEIRA, LG., 1998. Distribuição espacial de insetos aquáticos (Ephemeroptera, Plecoptera e Trichoptera) em córregos de cerrado do Parque Ecológico de Goiânia, Estado de Goiás. In NESSIMIAN, JL. and CARVALHO, AL. (Eds.). Ecologia de insetos aquáticos. Rio de Janeiro: PPGE-UFRJ. p. 175-189. Série Oecologia Brasiliensis, vol. V.

BISPO, PC., OLIVEIRA, LG., BINI, LM. and SOUSA, KG., 2006. Ephemeroptera, Plecoptera and Trichoptera assemblages from riffles in mountain streams of Central Brazil: environmental factors influencing the distribution and abundance of immatures. Brazilian Journal of Biology $=$ Revista Brasileira de Biologia, vol. 66, no. 2b, p. 611-622. http://dx.doi.org/10.1590/S151969842006000400005. PMid:16906293

CALLISTO, M., MELO, AS., BAPTISTA, DF., GONÇALVES JUNIOR, JF., GRAÇA, MAS. and AUGUSTO, FG., 2012. Future ecological studies of Brazilian headwater streams under global-changes.Acta Limnologica Brasiliensia, vol. 24, no. 3, p. 293-302. http://dx.doi.org/10.1590/S2179-975X2012005000047.

CALLISTO, M., GOULART, M., MEDEIROS, AO., MORENO, P. and ROSA, CA., 2004. Diversity assessment of benthic macroinvertebrates, yeasts, and microbiological indicators along a longitudinal gradient in Serra do Cipó, Brazil.Brazilian Journal of Biology $=$ Revista Brasileira de Biologia, vol. 64, no. 4, p. 743-755. http://dx.doi.org/10.1590/S1519-69842004000500003. PMid:15744414

CARVALHO, EM. and UIEDA, VS., 2004. Colonização por macroinvertebrados bentônicos em substrato artificial e natural em um riacho da serra de Itatinga, São Paulo, Brasil.Revista Brasileira de Zoologia, vol. 21, no. 2, p. 287-293. http://dx.doi. org/10.1590/S0101-81752004000200021.

CARVALHO, EM. and UIEDA, VS., 2006. Colonization routes of benthic macroinvertebrates in a stream in southeast Brazil. Acta Limnologica Brasiliensia, vol. 18, p. 367-376.

CARVALHO, EM. and UIEDA, VS., 2009a. Diet of invertebrates sampled in leaf-bags incubated in a tropical headwater stream. Zoologia (Curitiba), vol. 26, no. 4, p. 694-704. http://dx.doi. org/10.1590/S1984-46702009000400014.

CARVALHO, EM. and UIEDA, VS., 2009b. Seasonal leaf mass loss estimated by litter bag technique in two contrasting stretches of a tropical headstream.Acta Limnologica Brasiliensia, vol. 21, no. 2 , p. 209-215.

CARVALHO, EM. and UIEDA, VS., 2010. Input of litter in deforested and forested areas of a tropical headstream.Brazilian Journal of Biology $=$ Revista Brasileira de Biologia, vol. 70, no. 2, p. 283-288. http://dx.doi.org/10.1590/S1519-69842010005000015. PMid:20379655

CARVALHO, EM., UIEDA, VS. and MOTTA, RL., 2008. Colonization of rocky and leaf pack substrates by benthic macroinvertebrates in a stream in southeast Brazil.Bioikos, vol. 22 , no. 1 , p. 37-44.

CLARKE, KR. and GORLEY, RM., 2006. Primer v6: user manual/tutorial. Plymouth: Primer-E.

CRISCI-BISPO, VL.,BISPO, PC. and FROEHLICH, CG., 2007. Ephemeroptera, Plecoptera and Trichoptera assemblages in litter in a mountain stream of the Atlantic Rainforest from Southeastern Brazil.Revista Brasileira de Zoologia, vol. 24, no. 3, p. 545-551. http://dx.doi.org/10.1590/S0101-81752007000300004. 
CUMMINS, KW., 1974. Structure and function of stream ecosystems.Bioscience Journal, vol. 24, no. 11, p. 631-641. http:// dx.doi.org/10.2307/1296676.

CUMMINS, KW., 1988. The study of stream ecosystems: a functional view. In POMEROY, LR. and ALBERTS, JJ. (Eds.). Concepts of ecosystems ecology. New York: Springer-Verlag. p. $240-245$.

CUMMINS, KW. and KLUG, MJ., 1979. Feeding ecology of stream invertebrates.Annual Review of Ecology and Systematics, vol. 10 , no. 1 , p. 147-172. http://dx.doi.org/10.1146/annurev. es.10.110179.001051.

GONÇALVES JUNIOR, JF. and CALLISTO, M., 2013. Organicmatter dynamics in the riparian zone of a tropical headwater stream in Southern Brasil.Aquatic Botany, vol. 109, p. 8-13. http://dx.doi. org/10.1016/j.aquabot.2013.03.005.

GONÇALVES JUNIOR, JF., FRANÇA, JS., MEDEIROS, AO., ROSA, CA. and CALLISTO, M., 2006a. Leaf breakdown in a tropical stream.International Review of Hydrobiology, vol. 91, no. 2, p. 164-177. http://dx.doi.org/10.1002/iroh.200510826.

GONÇALVES JUNIOR, JF., GRAÇA, MAS. and CALLISTO, M., 2006b. Leaf-litter breakdown in 3 streams in temperate, Mediterranean, and tropical Cerrado climates.Journal of the North American Benthological Society, vol. 25, no. 2, p. 344-355.

GRAÇA, MAS., 2001. The role of invertebrates on leaf litter decomposition in streams - a review.International Review of Hydrobiology, vol. 86, no. 4-5, p. 383-393. http:// dx.doi.org/10.1002/1522-2632(200107)86:4/5<383::AIDIROH383>3.0.CO;2-D.

GRAÇA, MAS. and CANHOTO, C., 2006. Leaf litter processing in low order stream.Limnetica, vol. 25, no. 1-2, p. 1-10.

JUNKE, H. and TRIVINHO-STRIXINO, S., 2007. Colonization of leaf litter by aquatic macroinvertebrates: a study in a low order tropical stream.Acta Limnologica Brasiliensia, vol. 19, no. 1 , p. 109-115.

KIKUCHI, RM. and UIEDA, VS., 1998. Composição da comunidade de invertebrados de um ambiente lótico tropical e sua variação espacial e temporal. In NESSIMIAN, JL. and CARVALHO, AL. (Eds.). Ecologia de insetos aquáticos. Rio de Janeiro: PPGE-UFRJ. p. 157-173. Série Oecologia Brasiliensis, vol. V.

KREBS, CJ., 1989. Ecological methodology. New York: Harper \& Row Publishers, $654 \mathrm{p}$.

LEUNG, ASL. and DUDGEON, D., 2011. Scales of spatiotemporal variability in macroinvertebrate abundance and diversity in monsoonal streams: detecting environmental change.Freshwater Biology, vol. 56, no. 6, p. 1193-1208. http://dx.doi.org/10.1111/ j.1365-2427.2010.02556.x.

MORETTI, MS., GONÇALVES, JF., LIGEIRO, R. and CALLISTO, M., 2007. Invertebrates colonization on native tree leaves in a neotropical stream (Brazil).International Review of Hydrobiology, vol. 92, no. 2, p. 199-210. http://dx.doi.org/10.1002/iroh.200510957.

OLIVEIRA, LG. and FROEHLICH, CG., 1997. Diversity and community structure of aquatic insects (Ephemeroptera, Plecoptera and Trichoptera) in a mountain stream in southeastern Brazil.Acta Limnologica Brasiliensia, vol. 9, p. 139-148.
POZO, J., GONZÁLEZ, E., DÍEZ, JR., MOLINERO, J. and ELÓSEGI, A., 1997. Inputs of particulate organic matter to streams with different riparian vegetation.Journal of the North American Benthological Society, vol. 16, no. 3, p. 602-611. http://dx.doi. org/10.2307/1468147.

REZENDE, CF. and MAZZONI, R., 2005. Seasonal variation in the input of allochthonous matter in an Atlantic Rain Forest stream, Ilha Grande-RJ.Acta Limnologica Brasiliensia, vol. 17, no. 2 , p. 167-175.

RIBEIRO, OL. and UIEDA, VS., 2005. Estrutura da comunidade de macroinvertebrados bentônicos de um riacho de serra em Itatinga, São Paulo, Brasil.Revista Brasileira de Zoologi, vol. 22, no. 2, p. 613-618. http://dx.doi.org/10.1590/S0101-81752005000300013.

RODRIGUES, RR. and LEITÃO-FILHO, HF. (Eds.), 2001. Matas ciliares: conservação e recuperação. São Paulo: Edusp.

SCHINDLER, MH. and GESSNER, MO., 2009. Functional leaf traits and biodiversity effects on litter decomposition in a stream. Ecology, vol. 90, no. 6, p. 1641-1649. http://dx.doi.org/10.1890/081597.1. PMid: 19569378

SILVA-JUNIOR, ES. and MOULTON, TP., 2011. Ecosystem functioning and community structure as indicators for assessing environmental impacts: leaf processing and macroinvertebrates in Atlantic Forest streams.International Review of Hydrobiology, vol. 96, no. 6, p. 656-666. http://dx.doi.org/10.1002/iroh.201111374.

STANFORD, JA., 1996. Landscapes and catchment basins. In HAUER, FR. and LAMBERT, GA. (Eds.). Methods in stream ecology. San Diego: Academic Press. p. 3-22.

STATSOFT, 1996. Statistica 5.1 for windows. Computer Program Manual. Version 5.1.

UIEDA, VS. and KIKUCHI, RM., 1995. Entrada de material alóctone (detritos vegetais e invertebrados terrestres) num pequeno curso de água corrente na Cuesta de Botucatu, São Paulo.Acta Limnologica Brasiliensia, vol. 7, p. 105-114.

UIEDA, VS. and GAJARDO, ICSM., 1996. Macroinvertebrados perifíticos encontrados em poções e corredeiras de um riacho. Naturalia, vol. 21, p. 31-47.

UIEDA, VS. and MOTTA, RL., 2007. Trophic organization and food web structure of southeastern Brazilian streams: a review. Acta Limnologica Brasiliensia, vol. 19, no. 1, p. 15-30.

UIEDA, VS. and CARVALHO, EM., 2013. Leaflitter colonization by invertebrates analyzed through a manipulative experiment. Figshare. Available from: http://figshare.com/articles/Leaf_litter colonization_by_invertebrates_analyzed_through_a_manipulative experiment/888347>. Access in: 25 Jan. 2014.

VANNOTTE, RL., MINSHALL, GW., CUMMINS, KW., SEDELL, JR. and CUSHING, CE., 1980. The river continuum concept.Canadian Journal of Fisheries and Aquatic Sciences, vol. 37, no. 1, p. 130-137. http://dx.doi.org/10.1139/f80-017.

WALLACE, JB., EGGERT, SL., MEYER, JL. and WEBSTER, JR., 1997. Multiple trophic levels at a forest stream linked to terrestrial litter inputs.Science, vol. 277, no. 5322, p. 102-104. http://dx.doi.org/10.1126/science.277.5322.102.

ZAR, JH., 1999. Bioestatistical analysis. 4th ed. New Jersey: Prentice Hall. 960 p. 